\section{ACRL}

\section{Standards}

\title{
Standards for college libraries, 1995 edition
}

\section{Final version approved by the ACRL Board and the ALA Standards Committee, February 1995}

\section{Foreword}

These standards are intended to apply to libraries supporting academic programs at the bachelor's and master's degree levels. The 1995 edition retains the quantitative approach of the earlier editions. Smaller institutions or those with a strong media services component may find parts of the "Standards for community, junior, and technical college learning resources programs" useful. Larger institutions or those seeking a more process-oriented approach to standards may find sections of the "Standards for University Libraries" helpful. The "Standards for College Libraries" are based historically on practices found at institutions where libraries are providing effective support for the curriculum and for the scholarly and creative accomplishments of students and faculty (Kaser, 1982).

The 1995 edition of the standards has the following sections:

- Development and Approval of the Standards

- Introduction

- Standards and Commentaries

1. Mission, Goals, and Objectives

2. Collections

3. Organization of Materials

4. Staff

5. Services

6. Facilities

7. Administration

8. Budget

- Formula A, Collections
- Formula B, Librarians

- Formula C, Facilities

- Bibliography

- Committee Members, 1993-95 (see the list at the end of this article)

\section{DEVELOPMENT AND APPROVAL OF THE STANDARDS}

The first edition of the "Standards for College Libraries" was published in 1959. Subsequent editions were published in 1975 and 1986. The standards are the particular responsibility of the College Libraries Section Standards Committee, a standing committee of the Association of College and Research Libraries (ACRL) which is a division of the American Library Association (ALA).

The College Libraries Section Standards Committee is charged with the responsibility of ongoing review of the standards, consultation with the profession on their development and evaluation, and revision as needed. To that end, the committee conducted a national survey in $\mathbf{1 9 9 1 ,}$ and the results were reported in the May 1993 issue of College $\&$ Research Libraries (Walch, 1993). Hearings were held at the 1992 ACRL conference in Salt Lake City, and at the June 1994 ALA conference in Miami. The final version of the 1995 edition was approved by the College Libraries Section Executive Committee, the ACRL Standards and Accreditation Committee, the ALA Standards Committee, and the ACRL Executive Board of Directors at the 1995 Midwinter Meeting.

\section{INTRODUCTION}

Academic libraries are operating in the midst of extraordinary change in the scholarly communication system. The cost of the traditional system based on paper publication formats is 
becoming prohibitive, and electronic forms of communication are emerging rapidly. It is too early to tell how much electronic formats will supplant and how much they will only supplement paper formats. These changes raise many questions which will be answered in time. Time is the key; the evolution of this change cannot be predicted with precision. One speculation that seems possible to members of the 1993-95 Standards Committee is that the transition will take about thirty years, and we already have gone through the first ten years of the period.

In addition to changes in the scholarly communications system, there are many new trends that will change the way effective academic libraries operate. While a few can be recognized now through revisions to the commentaries for the standards, most are not developed well enough to be incorporated into the standards. It is important to be aware of these trends, and they are identified briefly here. The list is not intended to convey priorities.

- Escalating user expectations regarding information retrieval and document delivery times.

- Increased focus on accountability leading to more emphasis on assessment of student performance and interest in output measures as well as input measures.

- 'Virtual ownership' in lieu of local, physical ownership; acquiring materials 'just in time' instead of 'just in case'; title counts becoming more important than volume counts; rapid document delivery through electronic services; degradation of browsing opportunities.

- Stronger emphasis on services to persons with disabilities.

- Shifting patterns in the use of bibliographic utilities; fracturing of the national bibliographic databases; increased importance of networking and development of ANSI standards for search protocols; development of the 'national information highway.'

- Electronic storage and preservation of materials, e.g., reserve reading lists; digitization replacing microform.

- Traditional audiovisual resources evolving into multimedia and hypermedia.

- Computer equipment pervading library operations and facilities; greater need for staff training and user education in new technologies.
- Emergence of a paraprofessional group of library employees.

- Increased financial pressures for institutions and their libraries.

\section{STANDARDS AND COMMENTARIES}

Each standard is followed by commentary intended to amplify its intent and assist in its implementation.

\section{Standard 1: Mission, Goals, and Objectives}

1. The college library shall develop an explicit statement of its mission in accord with the mission of the college.

Commentary. It is accepted that the administration and faculty of every college have responsibility to examine the educational program from time to time in light of the goals and purposes of the institution. Librarians share this responsibility by seeking ways to provide collections and services which support those goals and purposes. Successful fulfillment of this shared responsibility can best be attained when a clear and explicit statement of library mission and goals is prepared and promulgated so that all members of the college community can understand and evaluate the appropriateness and effectiveness of the library program.

1.1 The development of library mission and goals shall be the responsibility of library personnel in consultation with members of the classroom faculty, administrative officers, and students.

Commentary. In developing these missions and goals the library should seek in a formal or structured way the advice and guidance of its primary users, the classroom faculty and students, and of the college administration, in particular those officers responsible for academic programs and policies.

1.2 The statement of library objectives shall be reviewed periodically and revised as necessary

Commentary. The articulation of library objectives is an obligation of the librarians, with the assistance of the support staff. In reviewing the objectives of the library, careful attention should be paid to ongoing advances in the theory and practice of librarianship. Similarly, changes occurring within the education program of the parent institution should be reflected in a timely way in the program of the library. 


\section{Standard 2: Collections}

2. The library's collections shall comprise all types of recorded information, including print materials in all formats, audiovisual materials, sound recordings, materials used with computers, graphics, and three-dimensional materials.

Commentary. Recorded knowledge and literary or artistic works appear in a wide range of formats. Books represent extended reports of scholarly investigations, compilation of findings, and summaries prepared for institutional purposes. The journal literature communicates more recent information and is particularly important to the science disciplines. Reports in machine-readable form are an even faster means of scholarly communication. Government documents transmit information generated by or at the behest of official agencies, and newspapers record daily activities throughout the world.

Many kinds of communication take place primarily, or exclusively, through such media as films, slidetapes, sound recordings, and videotapes. Microforms are used to compact many kinds of information for preservation and storage. Recorded information also exists in the forms of manuscripts, archives, databases, and computer software packages. Each medium of communication transmits information in unique ways, and each tends to complement the others.

The inherent unity of recorded information and its importance to all academic departments of an institution require that most, if not all, of this information be selected, organized, and made available for use by the library of that institution. In this way the institution's information resources can best be made known and balanced for the benefit of all users.

2.1 The library shall provide as promptly as possible a high percentage of materials needed by its users.

Commentary. The proper development of a collection includes concern for quality as well as quantity. A collection may be said to have quality for its purposes only to the degree that it possesses a portion of the bibliography of each discipline taught, appropriate in quantity both to the level at which each is taught and to the number of students and faculty members who use it. While it is possible to have quantity without quality, it is not possible to have quality without quantity in relation to the characteristics of the institution.
The library collection should be continually evaluated against standard bibliographies and evolving institutional requirements for purposes both of adding new titles and identifying for withdrawal those titles which have outlived their usefulness. No title should be retained for which a clear purpose is not evident in terms of academic programs or extracurricular enrichment.

The best way to preserve or improve quality in a college library collection is to adhere to rigorous standards of discrimination in the selection of materials to be added, whether as purchases or gifts. The collection should contain a substantial portion of the titles listed in standard bibliographies for the curricular areas of the institution and for supporting general fields of knowledge. Subject lists for college libraries have been prepared by several learned associations, while general bibliographies such as Books for College Libraries are especially useful for identifying important retrospective titles. A majority of the appropriate, current publications reviewed in scholarly journals and in reviewing media such as Choice or Library Journal should be acquired. Careful attention should also be given to standard works of reference and to bibliographical tools which describe the broad range of information sources.

Institutional needs for periodical holdings vary widely. In general it is good practice to consider owning any title that is needed more than five times per year. Several good lists have been prepared of periodical titles appropriate or necessary for college collections. Katz's Magazines for Libraries describes several thousand titles and is useful in this regard. It may not be necessary to subscribe to certain less frequently used titles if they are available at another library nearby, or if needed articles may be quickly procured through a reliable delivery system or by electronic means.

While it is important that a library have in its collection the quantity of materials called for in Formula A, its resources ought to be augmented whenever appropriate with external collections and services. A library that meets part of its responsibilities in this way must ensure that such activities do not weaken a continuing commitment to develop its own holdings. There is no substitute for a strong, immediately accessible collection. Moreover, once a collection has attained the size called for by this formula, its usefulness will soon di- 
minish if new materials are not acquired. Libraries with collections which are significantly below the size recommended in Formula $\mathrm{A}$ should maintain a $5 \%$ growth rate until they can claim a grade of A (see standard 2.2). Those that meet or exceed the criteria for a grade of $A$ may find it unrealistic or unnecessary to sustain a growth rate as high as $5 \%$.

Although the scope and content of the collection is ultimately the responsibility of the librarians, this responsibility can be best fulfilled by developing clear selection policies in cooperation with the classroom faculty. Moreover, the classroom faculty should be encouraged to participate in the selection of new titles for the collection.

2.2 The amount of print material to be provided by the library shall be determined by a formula (see Formula A) which takes into account the nature and extent of the academic program of the institution, its enrollment, and the size of the classroom faculty.

Commentary. A. Print resources. A strong core collection of print materials, augmented by specific allowances for enrollment, faculty size, and curricular offerings, is an indispensable requirement for the library of any college. The degree to which a library meets this requirement may be calculated with Formula A

B. Audiovisual resources. The range, extent, and configuration of nonprint resources and services in college libraries varies widely according to institutional needs and characteristics. Audiovisual holdings may be counted as volume unit equivalents and this number should be added to that for print volumes and volume-equivalents in measuring a library's collection against Formula A. If some or all of this material is housed in an administratively separate media center or audiovisual facility, it may be included in the grade determination if properly organized for use and readily accessible to the college community

C. Determination of grade. The degree to which a library provides its users with materials is graded by comparing the total holdings of volumes and volumeequivalents with the results of the Formula A calculation.

6. Allowance per master's field, when a higher degree is offered in the field*

7. Allowance per 6th year specialist degree field*
85,000 vols.

100 vols

15 vols.

350 vols

6,000 vols.

3,000 vols.

6,000 vols.

25,000 vols.

\section{Standard 3: Organization of materials}

3. Library collections shall be organized by nationally approved conventions and arranged for efficient retrieval at time of need.

commentary. The acquisition of library materials comprises only part of the task of providing access to them. Collections should be indexed and arranged systematically to assure efficient identification and retrieval.

3.1 There shall be comprehensive catalog of the library's holdings that permits identification of items, regardless of format or location, by author, title, and by subject as appropriate.

Commentary. The catalog should be comprehensive and 
provide bibliographic access to materials in all formats owned by the library. This can best be accomplished through the development of a catalog with items entered in accord with established national or international bibliographical conventions, such as rules for entry, descriptive cataloging, filing, classification, and subject headings.

Opportunities of several kinds exist for the cooperative development of the library's cata$\log$. These include the use of cataloging information produced by the Library of Congress and the various bibliographic utilities. It may also include the compilation by a number of libraries of a shared catalog. Catalogs should be subject to appropriate editing to keep them abreast of modern technology, contemporary practice, and changing national and international information standards such as MARC, AACR2, and NISO.

3.1.1 The catalog shall be in a format that can be consulted by a number of users concurrently.

Commentary. A public catalog in any format can satisfy this standard if it is so arranged that the library's users normally encounter no delay in gaining access to it.

3.1.2 In addition to the catalog there shall also be requisite subordinate files to provide bibliographic control and access to all library materials.

Commentary. Proper organization of the collections requires the maintenance of a number of subordinate files, such as authority files, shelf lists, and complementary catalogs, such as serial holdings records, as appropriate. Information contained in these files should also be available to library users. In addition, the content of library materials such as journals, documents, and microforms should be made accessible through indexes in printed or computer-based format.

3.2 Library materials shall be arranged to provide maximum accessibility to all users. Certain categories of materials may be segregated by form for convenience.

Commentary. Materials should be arranged so that related information can be easily consulted. Some materials such as rarities, manuscripts, or archives may be segregated for purposes of security or preservation. Materials in exceptionally active use, reference works, and assigned readings may be kept separate as reference and reserve collections to facilitate access to them. Audiovisual materials, maps, and microforms are examples of resources that may be awkward to integrate physically because of format and may need to be segregated from the main collection. Fragmentation of the collections should be avoided whenever possible, however, with the bulk of the collections shelved by subject in open stack areas to permit and encourage browsing.

3.3 Materials placed in storage facilities shall be readily accessible to users.

Commentary. Many libraries or groups of libraries have developed storage facilities for low-use materials such as sets or backruns of journals. These facilities may be situated on campus or in remote locations. The materials housed in these facilities should be easily identifiable and readily available for use in a timely fashion. If direct user access is not possible, a rapid retrieval system should be provided.

\section{Standard 4: Staff}

4. The staff shall be of adequate size and quality to meet the library's need for services, programs, and collection organization.

Commentary. The college library shall need a staff composed of qualified librarians, skilled support personnel, and student assistants to carry out its stated objectives.

4.1 Librarians, including the director, shall have a graduate degree from an ALA-accredited program, shall be responsible for duties of a professional nature, and shall participate in professional activities.

Commentary. The librarian has acquired through education in a graduate school of library and information science an understanding of the principles and theories of selection, acquisition, organization, interpretation, and administration of library resources. It should be noted that the MLS is regarded as a terminal professional degree by ALA and ACRL. Moreover, developments in computer and information technology have had a major impact on librarianship, requiring that librarians be well informed in this constantly developing area.

Librarians shall be assigned responsibilities which are appropriate to their education and which encourage the ongoing development of 
professional competencies. Participation in library and other professional activities on and off campus is also necessary to further personal development.

4.2 Librarians shall be organized as a separate academic unit such as a department or a school. They shall administer themselves in accord with ACRL's "Standards for Faculty Status for College and University Librarians" and institutional policies and guidelines.

Commentary. Librarians comprise the faculty of the library and should organize, administer, and govern themselves accordingly. The status, responsibilities, perquisites, and governance of the library faculty shall be fully organized and supported by the parent institution

4.3 The number of librarians required shall be determined by a formula (see Formula $\mathrm{B}$ ) and shall further take into consideration the goals and services of the library, programs, degrees offered, institutional enrollment, size of faculty and staff, and auxiliary programs.

Commentary. Formula B is based on student enrollment, collection size, and annual change in size of the collection. Other factors to be considered in determining staff size are services and programs, degrees offered, size of faculty and staff, and auxiliary programs. Examples of services and programs include reference and information services, bibliographic instruction, computer-based services, collection development, and collection organization. In addition, auxiliary programs, e.g., extension, community, and continuing education, as well as size and configuration of facilities and hours of service, are factors to be considered for determining adequate staff size.

4.4 The support staff and student assistants shall be assigned responsibilities appropriate to their qualification, training, experience, and capabilities. The support staff shall be no less than $65 \%$ of the total library staff, not including student assistants.

Commentary. Full-time and part-time support staff carry out a wide variety of paraprofessional, technical, and clerical responsibilities. A productive working relationship between librarians and support staff is an essential ingredient in the successful operation of the library. In addition, student assistants provide meaningful support in accomplishing many library tasks.

4.5 Library policies and procedures concerning staff shall be in accord with institutional guidelines and sound personnel management.

Commentary. The staff represents one of the library's most important assets in support of the instructional program of the college. Its management must be based upon sound, contemporary practices and procedures consistent with the goals and purposes of the institution, including the following:

1. Recruitment methods should be based upon a careful definition of positions to be filled and objective evaluation of credentials and qualification.

2. Written procedures should be developed in accordance with ACRL and institutional guidelines, and followed in matters of appointment, promotion, tenure, dismissal, and appeal.

3. Every staff member should be informed in writing as to the scope of his/her responsibilities.

4. Rates of pay and benefits of library staff should be equivalent to other positions on campus requiring comparable backgrounds.

5. There should be a structured program for orientation and training of new staff members, and career development should be provided for all staff.

6. Supervisory staff should be selected on a basis of job knowledge, experience, and human relations skills.

7. Procedures should be maintained for periodic review of staff performance and for recognition of achievement. See relevant ACRL documents listed in the bibliography.

\section{Standard 5: Services}

5. The library shall establish, promote, and maintain a range and quality of services that will support the academic program of the institution and encourage optimal library use.

Commentary. The primary purpose of college library service is to promote and support the academic program of the parent institution. Services should be developed for and made available to all members of the academic community, including persons with disabilities and nontraditional students. The successful fulfillment of this purpose will require that librarians work closely with classroom faculty to gain from them a clear understanding of their educational objectives and teaching methods and 
to communicate to them an understanding of the services and resources which the library can offer. While research skills and ease of access to materials will both serve and encourage library use, the primary motivation for students to use the library originates with the instructional methods used in the classroom. Thus, close cooperation between librarians and classroom faculty is essential. Such cooperation must result from planned and structured activity and requires that librarians participate in the academic planning councils of the institution. They should assist classroom faculty in appraising the actual and potential library resources available, work closely with them in developing library services to support their instructional activities, and keep them informed of library capabilities.

5.1 The library shall provide information and instruction to the user through a variety of techniques to meet differing needs. These shall include but not be limited to a variety of professional reference services, and bibliographic instruction programs designed to teach users how to take full advantage of the resources available to them.

Commentary. A fundamental responsibility of a college library is to provide instruction in the most effective and efficient use of its

\section{Formula B: Librarians}

For each 500 , or fraction thereof, FTE students up to 10,000

For each 1,000 or fraction thereof, FTE students above 10,000

For each 100,000 volumes, or fraction thereof, in the collection

For each 5,000 volumes, or fraction thereof, added and/or withdrawn per year
1 librarian

1 librarian

1 librarian

1 librarian

Enrollment, collection size, and growth of collection determine the number of librarians required by the college. These figures are to be calculated cumulatively. Libraries which provide $90-100 \%$ of these formula requirements can, provided they are supported by sufficient other staff members as described in Standard 4.4, consider themselves at the A level in terms of staff size; those that provide $75-89 \%$ of these requirements may rate themselves as $B$; those $60-74 \%$ of requirements qualify for a $\mathrm{C}$; and those with $50-59 \%$ requirement warrant a $\mathrm{D}$. This formula does not include campuswide media, archives, or academic computing services when administered by the library. Those units require additional personnel.

\section{Supplemental staffing factors to be considered}

\section{Organizational and Institutional}

The individual library's organization and institutional factors also influence its staffing needs. Additional factors to be considered are as follows:

Library

- Services and programs

- Size and configuration of facilities

- Hours of services

Examples of services and programs

- Reference and Information

- Bibliographic Instruction

- Computer Based Services

- Collection development

- Collection organization

- Archives

- Audiovisual services
Institutional

- Degrees offered

- Size of faculty and staff

- Auxiliary programs

Examples of institutional factors

- Undergraduate programs

- graduate programs

- Research

- Community

- Continuing education 
materials. Bibliographic instruction and orientation may be given at many levels of sophistication and may use a variety of methods and materials, including course-related instruction, separate courses (with or without credit), and group or individualized instruction.

Of equal importance is traditional reference service wherein individual users are guided by librarians in their appraisal of the range and extent of the library and information resources available to them for learning and research. Professional services are optimally available all hours the library is open. Use patterns should be studied to determine those times when the absence of professional assistance would be least detrimental. The third major form of information service is the delivery of information itself. Although obviously inappropriate in the case of student searches which are purposeful segments of classroom assignment, the actual delivery of information-as distinct from guidance to it - is a reasonable library service in almost all other conceivable situations.

Many of the services suggested in this commentary can be provided or enhanced by access to computerized forms of information retrieval. Many information sources are available only in computerized format, and every effort should be made to provide access to them. Services may be provided in person or through other means such as videocassette, computer programs, or other appropriately prepared programs.

5.2 Library materials of all types and formats that can be used outside the library shall be circulated to qualified users under equitable policies without jeopardizing their preservation or availability to others.

Commentary. Circulation of library materials should be determined by local conditions which will include size of the collection, the number of copies, and the extent of the user community. Every effort should be made to circulate materials of all formats that can be used outside the library without undue risk to their preservation. Circulation should be for as long a period as is reasonable without jeopardizing access to materials by other qualified users. This overall goal may prompt some institutions to establish variant or unique loan periods for different titles or classes of titles. Whatever loan policy is used, it should be equitable and uniformly administered to all qualified categories of users. The accessibility of materials can also be extended through provisions of inexpensive means of photocopying within the laws regarding copyright.

5.3 Interlibrary loan activities, cooperative programs, and utilization of commercial services shall be encouraged for the purpose of extending and increasing services and resources.

Commentary. The rapid growth of information sources, the availability of a variety of automation services, and the development of new technologies continue to impact a library's ability to provide services and resources. Cooperation with other institutions, and particularly with multitype library organizations, often becomes a necessity. This involves not only receiving, but also a willingness to give or share, on the part of each library. Formal reciprocal agreements, according to ALA codes, may need to be developed. Access to materials should be by the most efficient and rapid method possible, incorporating such measures as delivery services, rental services, and electronic mail in addition to, or in place of, traditional forms of delivery. The extent of resource sharing through ILL, cooperative arrangements, and other delivery methods should be recognized in any assessment of the ability of a library to supply its users with needed materiais.

5.4 The hours of access to the library shall be consistent with reasonable demand.

commentary. The number of hours per week that library services are available will vary as a reflection of reasonable local need. During peak hours of operation the users deserve competent, professional service. However, in some institutions users may need access to study facilities and to the collections, in whole or in part, during more hours of the week than they require personal assistance. In any case, the high value of the library's facilities, collections, associated materials, and equipment dictates that responsible personnel be on duty at all times.

5.5 Where academic programs are offered at off-campus sites, library services shall be provided in accord with ACRL's "Guidelines for Extended Campus Library Services."

Commentary. Special library problems exist for colleges that provide off-campus institutional programs. Students in such programs must 
be provided with library services in accord with ACRL's "Guidelines for Extended Campus Library Services." These guidelines suggest that such services be financed on a regular basis, that a librarian be specifically charged with the delivery of such services, that the library implications of such programs be considered before program approval, and that courses so taught encourage library use. Services should be designed to meet the different information and bibliographic needs of these users.

\section{Standard 6: Facilities}

6. The library building shall provide wellplanned, secure and adequate housing for its collections and personnel; secure space for users and staff; and space for the provision of services and programs.

Commentary. Successful library service presupposes an adequate library building. Although the type of building will depend upon the character and purposes of the institution, it should in all cases be functional, providing secure facilities for accommodating the library's personnel and resources, sufficient space for their administration and maintenance, and secure and comfortable reading and study areas for users. A new library building should represent a coordinated planning effort involving the library director and staff, the college administration, campus constituents, and the architect, with the director responsible for the preparation of the building program.

The needs of persons with disabilities should receive special attention and should be provided for in compliance with the Architectural Barriers Act of 1968 (Public Law 90-480) and the Rehabilitation Act of 1973, Section 504 (Public Law 93-516), and their amendments; and the Americans with Disabilities Act of 1990 (Public Law 101-336).

Particular consideration must be given to any present or future requirements for equipment associated with automated systems or other applications of library technology. Among these might be provision for new wiring, cabling, special climate control, and maximum flexibility in the use of space. Consideration should also be given to load-bearing requirements for compact shelving and the housing of mixed formats including microforms.

6.1 The size of the library building shall be determined by a formula (see Formula $\mathrm{C}$, next page) which takes into account the enrollment of the college, the extent and nature of its col lections, and the size of its staff.

6.2 In designing or managing a library building, the functionality of floor plan and the use of space shall be the paramount concem.

Commentary. The quality of a building is measured by such characteristics as the utility and comfort of its study and office areas, the design and durability of its furniture and equipment, the functional interrelationships of its service and work areas, and the ease and economy with which it can be operated and used.

6.3 Except in certain circumstances, the college library's collections and services shall be administered within a single structure.

Commentary. Decentralized library facilities in a college have some virtues, and they present some difficulties. Primary among their virtues is the convenience to the offices or laboratories of some of the classroom faculty. Primary among their weaknesses is the resulting fragmentation of the unit of knowledge, the relative isolation of a branch library from most users, potential problems of staffing and security, and the cost of maintaining certain duplicate services or functions. When decentralized library facilities are being considered, these costs and benefits must be carefully compared. In general, experience has shown that decentralized library facilities may not be in the best academic or economic interest of a college.

\section{Standard 7: Administration}

Matters pertaining to college library administration are treated in the several other standards. Matters of personnel administration, for example, are discussed in standard 4, and fiscal administration in standard 8. Some important aspects of library management, however, must be considered apart from the other standards.

7. The college library shall be administered in a manner which permits and encourages the fullest and most effective use of available library resources.

Commentary. The function of a library administrator is to direct and coordinate the components of the library-its staff, services, collections, buildings, and external relations. Each component contributes effectively and imaginatively to the mission of the library. 
7.1 The statutory or legal foundation for the library's activities shall be recognized in writing.

Commentary. In order for the library to function effectively, there must be an articulated understanding within the college as to the statutory or legal basis under which the library operates. This may be a college bylaw, a trustee minute, or a public law which shows the responsibility and flow of authority under which the library is empowered to act.

7.2 The library director shall be an officer of the college and shall report to the president or the chief academic officer of the institution.

Commentary. For the closest coordination of library activities with the instructional program, the library director should report to either the president or the chief officer in charge of the academic affairs of the institution.

7.2.1 The responsibilities and authority of the library director and procedures for appointment shall be defined in writing.

Commentary. There should be a document defining the responsibility and authority vested in the library director. This document may also be statutorily based and should spell out, in addition to the scope and nature of the director's duties and powers, the procedures for appointment.

7.3 There shall be a standing advisory committee comprised of students and members of the classroom faculty which shall serve as a channel of formal communication between the library and its user community.

Commentary. This committee - of which the library director should be an ex-officio member-should be used to convey both an awareness to the library of its users' concerns, perceptions, and needs, and an understanding to users of the library's objectives and capabilities. The charge to the committee should be specific and in writing.

\section{Formula C: Facilities}

The size of the college library building shall be calculated on the basis of a formula which takes into consideration the size of the student body, the size of the staff and its space requirements, and the number of volumes in the collection. To the result of this calculation must be added such space as may be required to house and service nonprint materials and microforms, to provide bibliographic instruction to groups, and to accommodate equipment and services associated with various forms of library technology. The formula may need to be adjusted in accordance with local interpretation and application of the requirements of the Americans with Disabilities Act of 1990.

a. Space for users. The seating requirement for the library of a college when less than $50 \%$ of the FTE enrollment resides on campus shall be one for each five students. That for the library of a typical residential college shall be one for each four FTE students. Each study station shall be assumed to require 25 to 35 square feet for floor space, depending upon its functions.

b. Space for books. The space allocated for books shall be adequate to accommodate a convenient and orderly distribution of the collection according to the classification system(s) in use, and should include space for growth. Gross space requirements may be estimated according to the following formula:

For the first 150,000 volumes For the next 150,000 volumes For the next 300,000 volumes For holdings above 600,000 volumes
Square Feet/Volume
0.10
0.09
0.08
0.07

c. Space for staff. Space required for staff offices, service and work areas, catalogs, files, and equipment shall be approximately one-eighth of the sum of the space needed for books and users as calculated under a) and b) above.

This formula indicates the net assignable area required by a library if it is to fulfill its mission with maximum effectiveness. "Net assignable area" is the sum of all areas (measured in square feet) on all floors of a building, assignable to, or useful for, library functions or purposes. (For an explanation of this definition see Measurement and Comparison of Pbysical Facilities for Libraries, ALA, 1970.)

Libraries which provide $90-100 \%$ of the net assignable area called for by the formula shall be graded $\mathrm{A}$ in tems of space; 75-89\% shall be graded $\mathrm{B} ; 60-74 \%$ shall be graded $\mathrm{C}$; and $50-59 \%$ shall be graded D. 
7.4 The library shall maintain written policies and procedures manuals covering internal library governance and operation activities.

Commentary. Written policies and procedures manuals are required for good management, uniformity, and consistency of action. They also aid in training staff and contribute to public understanding

7.4.1 The library shall maintain a systematic and continuous program for evaluating its performance, for informing the community of its accomplishments, and for identifying needed improvement.

Commentary. The library director, in conjunction with the staff, should develop a program for evaluating the library's performance. Objectives developed in accordance with the goals of the institution should play a major part in this evaluation program. Statistics should be maintained for use in reports, to demonstrate trends, and in performance evaluation. At the discretion of the library director and in accordance with institutional requirements, the statistics may include data related to input measures, output measures, and/or assessment. In addition, the library director and staff members should seek the assistance of the standing library advisory committee and other representatives of the community.

7.5 The library shall be administered in accord with the spirit of the ALA "Library Bill of Rights."

Commentary. College libraries should be impervious to the pleasures or efforts of any special interest groups or individuals to shape their collections and services. This principle, first postulated by the American Library Association in 1939 as the "Library Bill of Rights" (amended 1948, 1961, 1967, and 1980 by the ALA Council), should govern the administration of every college library and be given the full protection of the parent institution.

\section{Standard 8: Budget}

8. The library director shall have the responsibility for preparing, defending, and administering the library budget in accord with agreed upon objectives.

Commentary. The library budget is a function of program planning and defines the library's objectives in fiscal terms. The objectives formulated under Standard 1 should con- stitute the base upon which the library's budget is developed.

8.1 The library's annual authorized expenditures shall be at least six percent of the total institutional expenditure for educational and general purposes. The library shall receive its appropriation at the beginning of the budget cycle for the institution.

Commentary. The degree to which the college is able to fund the library in accord with institutional objectives is reflected in the relationship of the library appropriation to the total educational and general budget of the college. It is recommended that library budgets, exclusive of capital costs and the costs of physical maintenance, not fall below six percent of the college's total educational and general expenditures if the library is to sustain the range of programs required by the institution and meet appropriate institutional objectives. This percentage should be greater if the library is attempting to overcome past deficiencies, or to meet the needs of new academic programs. The six percent figure is intended to include support for separately established professional libraries, providing the budget for those schools is incorporated into that of the college or university.

Factors which should be considered in formulating a library's budget requirements are the following:

1. The scope, nature, and level of the college curriculum;

2. Instructional methods used, especially as they relate to independent study;

3. The adequacy of existing collections and the publishing rate in fields pertinent to the curriculum;

4. The size, or anticipated size, of the student body and classroom faculty;

5. The adequacy and availability of other library resources;

6. The range of services offered by the library, for example, the number of service points maintained, the number of hours per week that service is provided, the level of bibliographic instruction, online services, etc.;

7. The extent of automation of operations and services, with attendant costs;

8. The extent to which the library already meets the "Standards for College Libraries."

8.1.1 The library's appropriation shall be augmented above the six percent level depend- 
ing on the extent to which it bears responsibility for acquiring, processing, and servicing audiovisual material, and microcomputer resources.

Commentary. It is difficult for an academic library that has not traditionally been purchasing microcomputer and audiovisual materials to accommodate such purchases without some budgetary increase. The level of expenditure depends upon whether or not the institution has an audiovisual center separate from the library that acquires and maintains both audiovisual materials and hardware as well as a computer center that absorbs all costs related to microcomputer resources, even those included in the library.

8.2 The library director shall have sole authority to apportion funds and initiate expenditures within the library budget and in accord with institutional policy.

Commentary. Procedures for the preparation and defense of budget estimates, policies on budget approval, and regulation concerning accounting and expenditures vary from one institution to another. The library director must know and conform to local procedure. Sound practices of planning and control require that the director have sole responsibility and authority for allocation-and within college policy, the reallocation-of the library budget and the initiation of expenditures against it. Depending upon local factors, between $35 \%$ and $45 \%$ of the library's budget is normally allocated to acquisition of resources, and between $50 \%$ and $60 \%$ is expended for personnel.

8.3 Any revenues generated by the library from fees and charges such as fines, payment for lost or damaged materials, and from the sale of duplicate or unneeded items should be retained by the library for support of collections and services.

Commentary. In some jurisdictions, local laws place restrictions on this concept. However, it is acceptable practice in many areas now, and the committee would like to see the practice encouraged.

8.4 The library shall maintain internal accounts for approving its invoices for payment, monitoring its encumbrances, and evaluating the flow of its expenditures.

Commentary. Periodic reports are necessary and provide an accurate account of the funds allocated to the library. They should be current and made accessible for fiscal accountability.

\section{Bibliography}

ACRL. "Guidelines for Audiovisual Services in Academic Libraries. CERL News 48 (October 1987): 533-36.

ACRL. "Guidelines for Extended Campus Library Services." CERL News 51 (April 1990): 353-55.

ACRL. "Model Statement for the Screening and Appointment of Academic Librarians Using a Search Committee." CERL News 53 (November 1992): 642-45.

ACRL. "Model Statement of Criteria and Procedures for Appointment, Promotion in Academic Rank, and Tenure for College and University Librarians." CERL News 48 (May 1987): 247-54.

ACRL. "Model Statement of Objectives for Academic Bibliographic Instruction." CERL News 48 (May 1987): 256-61.

ACRL. "Standards for Community, Junior, and Technical College Learning Resources Programs." CERL News 51 (September 1990): $757-67$.

ACRL. "Standards for Faculty Status for College and University Librarians." CERL News 53 (May 1974): 317-18.

ACRL. "Standards for University Libraries: Evaluation of Performance." CERL News 50 (September 1989): 679-91.

ACRL. "Statement on the Terminal Professional Degree for Academic Librarians." Chicago: ALA/ACRL, 1975.

ALA, Ad Hoc Committee on the Physical Facilities of Libraries. Measurement and Comparison of Pbysical Facilities for Libraries. Chicago: ALA, 1970.

ALA. "Library Bill of Rights" (ALA Policy Manual, Section 53.1). In ALA Handbook of Organization 1993/1994. Chicago: ALA, 1993, p. H147.

ALA. "Library Education and Personnel Utilization: A Statement of Policy." Adopted by ALA Council. Chicago: ALA/OLPR, 1970.

ALA, RSDA/FLA. National Interlibrary Loan Code, 1980; International Lending Principles and Guidelines, 1978. Chicago: ALA, 1982.

Carpenter, Ray L. "College Libraries: A Comparative Analysis in Terms of the ACRL Standards." College \& Research Libraries 42 (January 1981): 7-18.B

Coleman, Paul, and Ada Jarred. "Regional Ac- 
creditation Criteria and the Standards for College Libraries: The Informal Role of Quantitative Input Measures for Libraries in Accreditation," Journal of Academic Librarianship 20 (November 1994): 273-84.

Hardesty, Larry, and Stella Bentley. The Use and Effectiveness of the 1975 Standards for College Libraries: A Survey of College Library Directors (1981).. Unpublished paper.

Kaser, David. "Standards for College Libraries." Library Trends 31:1 (Summer 1982): 7-19.

Kroll, Susan, ed. Academic Status: Statements and Resources, 2 nded. Chicago: ACRL/ALA, 1994.

Leach, Ronald G., and Judith E. Tribble. "Electronic Document Delivery: New Options for Libraries." Joumal of Academic Librarianship 18 (January 1993): 359-64.

Matier, Michael, and C. Clinton Sidle. "What Size Libraries for 2010?" Planning for Higher Education 21 (Summer 1993): 9-15.

Morgan, Robert L. Classification of Instructional Programs, 1990 edition. Washington, D.C.: National Center for Education Statistics, 1991.
Sacks, Patricia Ann, and Sara Lou Whildin. Preparing for Accreditation; a Handbook for Academic Librarians. Chicago: ALA, 1993.

Stueart, Robert D., and Barbara B. Moran.

"Missions, Goals and Objectives." In Library and Information Center Management, 4th ed. Englewood, Colo.: Libraries Unlimited, 1993, pp. 43-45.

U.S. Code. 1-810. "Act for the General Revision of the Copyright Law." October 9, 1976. Public Law 94-553,90 Stat. 2541.

Walch, David B. "The 1986 College Library Standards: Application and Utilization." College E Research Libraries 54 (May 1993): 217-26.

(Ed. note: Committee members ubo worked on the 1995 edition are: Diane C. Parker, chair, Western Wasbington University; Barbara Bryan, Fairfield University; Paul Coleman, Adrian College; Jan Fennell. Geongia College, Milledgeville; Dalia Hagan, St.Martins College; Ada Jarred, Nortbwestern State University of Louisiana; Eric Kidwell, Huntingdon College; Grady Morein, University of West Florida; and Norma Yueb, Ramapo College of New Jersey.)
(Actions cont. from page 240)

for Law Librarians with a cash prize of $\$ 1,000$ and a citation donated by Congressional Quarterly.

\section{Approved a recommendation to redefine} the Professional Liaison Committee and designated the Executive Director to chair the committee.

Approved ACRL Priorities for 1995-1996. The priorities are:

1) Expand information, programs, and delivery mechanisms that will enhance the leadership abilities of academic librarians.

2) Provide leadership within the higher education community on library and information issues.

3) Build strategic alliances among ACRL units, ALA divisions, and the broader higher education community to advance ACRL priorities.

Approved an amendment to the Initiative Fund Criteria to include projects supporting ALA Goal 2000.

Approved the addition of a Board/Leadership meeting to its scheduled official meetings held at Annual Conferences and Midwinter Meetings.

Approved the discontinuance of the regional appointment basis for the Membership Committee and established a task force to develop a new strategy.

Approved the ACRL/CNI (Coalition for Networked Information) preconference, "The Networked Professional," for 1996 in New York.

Established a policy for reporting to the Board on funded initiative projects that requires project directors to submit a report of activities at the time the request is made for final payment.

Approved 0.95 FTE staff increase for the 1996 budget year to support ACRL's production of College $\&$ Research Libraries and to handle conference and preconference activities like registration and exhibits management.

Approved the 1996 preliminary budget with revenue of $\$ 974,967$ and expenses of $\$ 1,211,306$. 